\title{
43. A PLATE TECTONIC RECONSTRUCTION OF THE SOUTHWEST PACIFIC, 0-100 Ma ${ }^{1}$
}

\author{
Chun Yeung Yan ${ }^{2}$ and Loren W. Kroenke ${ }^{3}$
}

\begin{abstract}
Southwest Pacific paleogeography has been reconstructed back to $100 \mathrm{Ma}$ on the basis of the hotspot frame of reference. Plate circuits for all key tectonic elements have been determined with respect to the Indo-Australia (I-A), Antarctica, and Pacific plates, using hotspot trails on the India, Australia, and Pacific plates to constrain the motions of all the plates. Paleo-locations of rifted continental margins, oceanic plateaus, subduction zones, and marginal basins have been reconstructed for the Southwest Pacific in a series of palinspastic maps that are thought to closely portray the tectonic development of the Southwest Pacific during the last 100 m.y. Successive periods of convergence are shown occurring along five different paleo-subduction zones that formed concomitantly with changes in I-A and Pacific plate motions from the Eocene to the late Miocene along the Papuan-Rennell-New Caledonia-Norfolk (55-40 Ma), Manus-North Solomon-Vitiaz (43-25 Ma), New Guinea-proto-Tonga-Kermadec (27-10 Ma), New Britain-San Cristobal-New Hebrides (12-0 Ma), and Tonga-Kermadec (10-0 Ma) trenches. Episodes of basin formation are shown occurring along the western and southwestern margins of the Pacific Plate and along the eastern and northeastern margins of the I-A Plate from the Late Cretaceous to the present, including the Tasman (85-55 Ma), New Caledonia (74-65 Ma), Coral Sea (63-53 Ma), Loyalty (52-40 Ma), d'Entrecasteaux (34-28 Ma), Caroline (34-27 Ma), Solomon Sea (34-28 Ma), South Fiji (34-27 Ma), North Fiji (10-0 $\mathrm{Ma})$, and Lau, Woodlark, and Manus (5.5-0 Ma) basins. Seamount chains are also shown developing over the Tasmantid, Lord Howe, Louisville, and Samoa hotspots.
\end{abstract}

\section{INTRODUCTION}

Information obtained during the past two decades on the regional geological framework of the Southwest Pacific in concert with new data on Indo-Australia (I-A) and Pacific plate motions was used to constrain reconstruction of past locations of tectonic elements (such as convergent and divergent plate boundaries), physiographic provinces, and intraplate volcanic centers. Charting of these features back in time is important for recognizing the influence of tectonism on regional geology and patterns of sediment distribution, elucidating paleogeographic effects on depositional history, and identifying provenance of ash horizons observed in the sedimentary column (see Kroenke et al., this volume).

Studies of the regional geological framework of the Southwest Pacific reveal that outward migration of the I-A/Pacific plate boundary has progressed through the development of a succession of island arcs and formation of a series of dilational basins. The complex of submarine ridges and arcuate island chains concentric to eastern and northeastern Australia, shown in Figure 1, attests to the presence of rifted continental fragments and fossil subduction zones. Some of the latter exhibit low levels of seismicity that suggest recent reactivation. Interspersed between these features lie the marginal and backarc basins of the Southwest Pacific (Fig. 1).

In a regional tectonic synthesis, Kroenke (1984) identified tectonic elements and documented the sequence of events that occurred within the Southwest Pacific during the Cenozoic. He concluded that successive periods of convergence occurred sequentially along different subduction zones within the region in the Eocene, Oligocene, early to late Miocene, and late Miocene to Holocene. Collision tectonism was shown to have occurred repeatedly, causing emplacement of the ultramafic belt in Papua New Guinea ( 43-37 Ma),

\footnotetext{
'Berger, W.H., Kroenke, L.W., Mayer, L.A., et al., 1993. Proc. ODP, Sci. Results, 130: College Station, TX (Ocean Drilling Program).

${ }^{2}$ Geodynamics Research Institute and Department of Geophysics, Texas A\&M University, College Station, TX 77843, U.S.A.

${ }^{3}$ School of Ocean and Earth Science and Technology, University of Hawaii, 2525 Correa Road, Honolulu, HI 96822, U.S.A.
}

emplacement of the peridotite nappes in New Caledonia $(\sim 39$ $36 \mathrm{Ma})$, reactivation of the North Solomon Subduction Zone, overthrusting of Santa Isabel in the Solomon Islands, formation of the Malaita Anticlinorium ( 4-0 Ma), and suturing of an element of the West Melanesian Arc to the New Guinea mainland and reactivation of the New Guinea subduction zone ( 2-0 Ma). Episodes of marginal basin formation occurring along the eastern and northeastern I-APlate from the Late Cretaceous to the present were identified.

It is possible to reconstruct the locations of these Southwest Pacific tectonic elements back in time, first by determining the linkages between individual rifted continental fragments or island arcs, adjoining marginal or backarc basins, and contiguous plate margins (i.e., plate circuits), and second by assigning the correct plate motions derived from hotspot models to the appropriate tectonic elements by means of these plate circuits. The hotspot frame of reference, because it is considered by many workers to be fixed with regard to an absolute global coordinate system (Morgan, 1981, 1983; Duncan, 1981, 1991; Duncan and Richards, 1991; Fleitout and Moriceau, 1992), provides an ideal frame of reference for plate reconstructions. Furthermore, by confining these reconstructions to the time span 0-100 Ma, the period for which hotspot trails have been clearly delineated, only the motions of the I-A and Pacific plates as defined by the hotspot models and the dilational history of intervening marginal and backarc basins need to be considered in making the reconstructions.

Reconstructions of the tectonic elements and physiographic provinces shown in Figure 1 are presented here at key points in time from $100 \mathrm{Ma}$ to the present. The geologic time scale and the age of magnetic anomaly chrons used in the reconstruction is taken from Harland et al. (1990). The timing of tectonic events, in particular the beginning and ending of subduction, unless otherwise referenced, is from Kroenke (1984). Magnetic anomaly lineations used in, and shown on, the reconstructions are taken from Larue et al. (1977), Weissel and Hayes (1977), Weissel and Anderson (1978), Shaw (1979), Taylor (1979), Lapouille (1982), Maillet et al. (1982), Malahoff et al. (1982), Hegarty et al. (1983), Joshima et al. (1987), Taylor (1987), Hegarty and Weissel (1988), Cande et al. (1989), Jarvis (1991), and Malahoff et al. (in press). Hotspot models and plate circuits used in determining the motion of the I-A and Pacific plates and in reconstructing the location of features are discussed below. A CD-ROM containing an animated 
version of this reconstruction in 0.5-m.y. steps is also included at the back of this volume. ${ }^{4}$

\section{HOTSPOT MODELS: ROTATION POLES AND ANGLES}

Computer modeling of hotspot tracks is based on the hypothesis that hotspots are maintained by stationary or fixed mantle sources (Morgan, 1981; Duncan, 1981). Although some workers still favor considerable motion between hotspots (see, for example, Jurdy and Stefanick, 1991), most workers now agree that inter-hotspot motion must be relatively insignificant (Acton and Gordon, 1990; Duncan and Richards, 1991). Indeed, Duncan (1991) notes that the close correspondence between volcanic trails on the I-A Plate and the computer-modeled hotspot tracks projected from the African Plate onto the I-A Plate is strong evidence that hotspots remain fixed for significant periods of time (100 m.y.) over large areas of the globe. For the purpose of this study, hotspots on the I-A and Pacific plates are assumed to be fixed. The close correspondence between co-polar segments of volcanic trails within the Tasman Basin and along eastern Australia on the I-A Plate (Yan, 1988) and between those of the Hawaiian-Emperor and Louisville trails on the Pacific Plate (Lonsdale, 1988; Fleitout and Moriceau, 1992) further supports the validity of this assumption.

Changes or bends in the trajectory of I-A Plate motion have been recognized at 12,16, 27, 43, and $55 \mathrm{Ma}$ (Yan, 1988), and also at $\sim 84 \mathrm{Ma}$ Duncan (1991). Bends in the Pacific Plate trajectory have been recognized at 24, 43, 55, 65, 74, and $100 \mathrm{Ma}$ (Epp, 1978; Duncan, 1981). Rotation poles and rates previously had been determined by Yan (1988) for I-A Plate motion for the time span 55-0 Ma. Using the same method, a rotation pole was fitted to Ninetyeast Ridge on the India Plate with the rotation rate adjusted to match the new ages determined by Duncan (1991). Australia Plate rotation poles and angles were then calculated for the time span 84-55 Ma by projection through the India-Antarctica-Australia plate circuit using the relative motions between India-Antarctica and Antarctica-Australia given by Royer and Sandwell (1989). In similar fashion, a rotation pole was fitted to a collinear hotspot trail inferred to lie along the northern margin of the northern Kerguelen Plateau, assuming that slow eastsoutheast motion of the combined Broken Ridge-Kerguelen plateaus occurred over the hotspot for the preceding $15 \mathrm{~m}$.y. Australia poles and angles were then calculated for the time span 100-84 Ma by projection through the Antarctica-Australia plate circuit (Royer and Sandwell, 1989). Australia rotation poles and angles thus determined for the time span 0-100 Ma are given in Tables 1-4. Computer-modeled hotspot tracks and the apparent polar wander path for the Australia portion of the I-A Plate are shown in Figure 2. Note that there is close correspondence between the Australian apparent polar wander path in Figure 2 and that given by Musgrave (1989) for the time span 85-100 Ma.

New rotation poles and angles were also determined for the Pacific Plate motion for the time span 0-94 Ma using the methods described by Yan (1988). Rotation poles were fitted to the Hawaiian-Emperor and Louisville trails for the time span 0-65 Ma with rates adjusted to match Hawaiian-Emperor ages given by Clague and Dalrymple (1989) and Louisville ages given by Lonsdale (1988). A rotation pole was also fitted to the Musician trail for the time span 74-94 Ma with

\footnotetext{
${ }^{4}$ The reconstruction is contained in two readable/executable files on the CD ROM (in back pocket) that can be run on any IBM PC compatible that has a VGA monitor attached. They are FORWARD.EXE and BACKWARD.EXE, which will run the reconstructions forward and backward in time, respectively. The files either may be executed directly from your CD-ROM drive or may be copied to and run from your PC hard drive, providing you have sufficient disk space available. To run one of the files from your hard drive, roughly 9 megabytes of disk space must be available; to run both files, about 18 megabytes must be available.
}

rates adjusted to match new ages given by Pringle (1992). This pole was then extrapolated back to $100 \mathrm{Ma}$. For the time span $65-74 \mathrm{Ma}$, the rotation pole was taken from Duncan and Clague (1985). Pacific rotation poles and angles thus determined are given in Tables 5-7 for the time span 0-100 Ma. Computer-modeled hotspot tracks for the Pacific Plate are shown in Figure 3. Because of uncertainties in timing and location of poles of rotation, recent changes in Pacific Plate motion, such as the Pliocene change proposed by Engebretson et al. (1985), have not been incorporated in this new model. Nevertheless, the new model achieves much closer correspondence between co-polar segments of the Hawaiian-Emperor and Louisville trails for the time span 0-65 Ma than that of previous models. Good agreement also is observed between this new model and the motions of the Pacific Plate with respect to hotspots given by Fleitout and Moriceau (1992).

Finite and/or total poles of opening for all the marginal basins of the Southwest Pacific, except for the Tasman and Coral Sea basins, were determined using the method described by Scotese et al. (1988). Poles and angles of opening for the Tasman and Coral Sea basins were taken from Shaw (1979). For most of the other basins, magnetic anomaly lineations and/or fracture zone alignments were used to determine poles of opening. Magnetic anomalies and local geology were used to provide age constraints. Data sources, poles and angles of opening, and age ranges for all marginal basins used in the reconstructions are listed in Tables 8-9.

\section{PLATE CIRCUITS}

Plate circuits were determined for each of the tectonic elements shown in Figure 1 by tying the various elements by means of adjoining marginal or backarc basins to the appropriate contiguous major plate without crossing any convergent boundaries. The plate circuits thus determined are given in Table 10 and are described below. The motion of each element was then determined through these circuits using the total and/or finite poles and angles of opening of intervening dilational basins, as described above, coupled to the motion of the major plate as derived from the hotspot models, also described above. The salient points of the resulting plate circuits are discussed below, backward in time in the same sequence as the reconstruction shown in Figure 4 was developed.

\section{Pacific-Australia Circuits}

Between 0 and $10 \mathrm{Ma}$, the New Britain-San Cristobal-New Hebrides arcs were tied to the Pacific Plate-New Britain by means of the Manus Basin spreading ridge ( $0-6 \mathrm{Ma}$ ) and New Hebrides by means of the North Fiji Basin spreading ridges (0-10 Ma). The Tonga-Kermadec Arc is tied to the Australia Plate by means of the Lau-Havre spreading ridges (0-6 Ma). Exceptions occur (1) between 0 and $4 \mathrm{Ma}$, when motion across the New Britain-San Cristobal arcs was distributed equally between the Pacific and Australia plates to correct for the opening of the Woodlark Basin (tied to the Australia Plate) and to correct for the obduction of the Ontong Java Plateau (attached to the Pacific Plate); and (2) between 0 and 2 Ma when motion across Papua New Guinea was distributed between the Australia and Bismarck plates to correct for collision of the New Britain forearc (northern New Guinea-Huon peninsula) with the Papua New Guinea mainland.

In the North Fiji Basin, where the motion was quite complicated (see Jarvis, 1991; Kroenke et al., in press; Malahoff et al., in press) the New Hebrides Arc was tied to the Pacific Plate by means of the northwestern limb of the Central North Fiji Basin (CNFB) triple junction $(0-7 \mathrm{Ma})$, rotating counterclockwise back toward the Pacific Plate, whereas the Fiji Platform was tied to the New Hebrides Arc first $(0-1.5 \mathrm{Ma})$ by means of two spreading centers (the southern limb of the CNFB triple junction and the Viwa Rift west of Fiji) and next (1.5-7 Ma) by means of the southern limb of the CNFB triple junction 


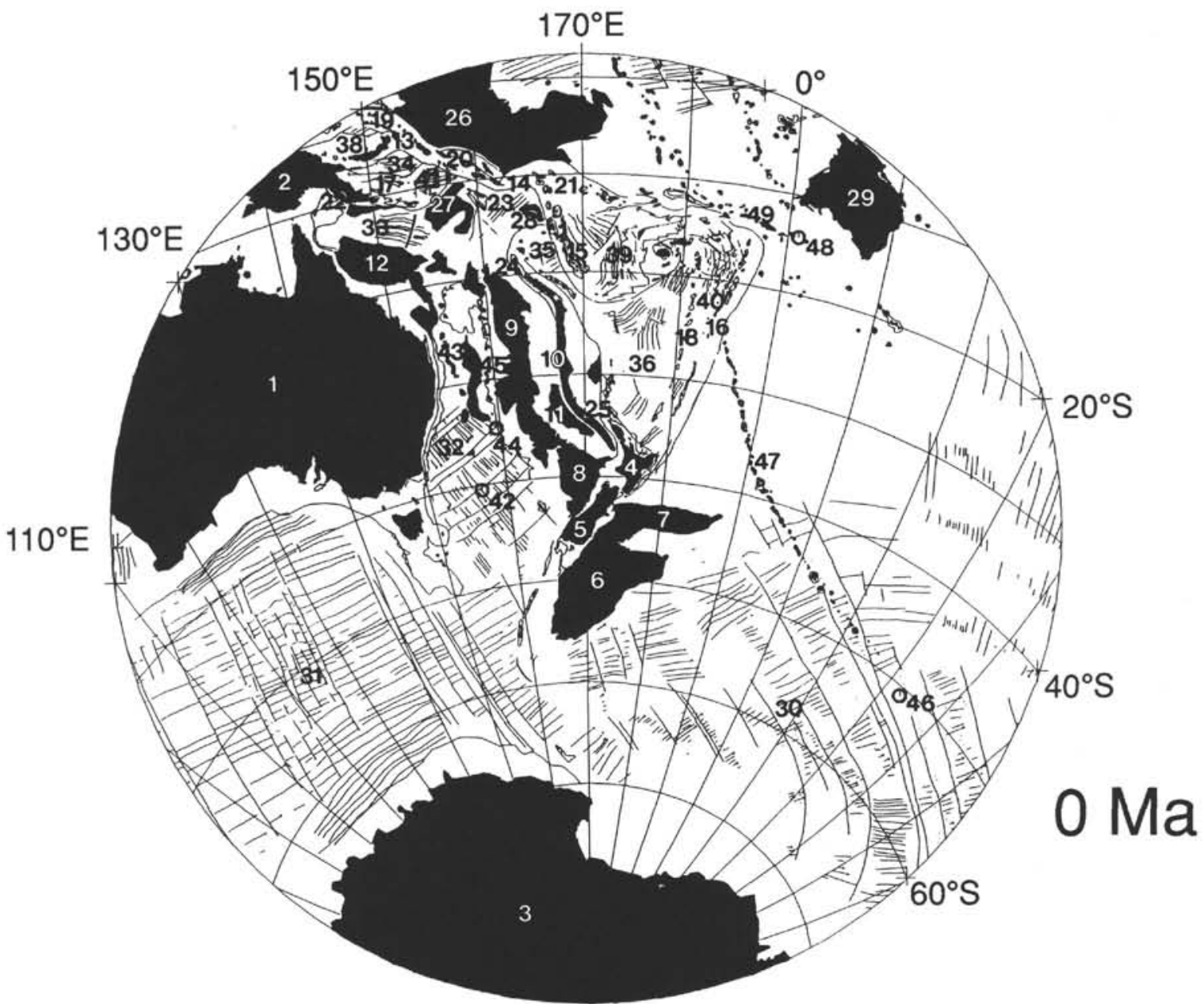
1. Australia
2. Papua New Guinea
3. Antarctica
4. New Zealand North Island
5. New Zealand South Island
6. Campbell Plateau
7. Chatham Rise
8. Challenger Plateau
9. Lord Howe Rise
10. Norfolk Ridge
11. West Norfolk Ridge
12. Queensland Plateau
13. New Britain Arc
14. San Cristobal Arc
15. New Hebrides Arc
16. Tonga-Kermadec Arc

17. New Guinea Arc
18. Lau-Colville Arc
19. Manus Arc
20. North Solomon Arc
21. Vitiaz Arc
22. Papuan Arc
23. Rennell Arc
24. New Caledonia Arc
25. Norfolk Arc
26. Ontong Java Plateau
27. Louisiade Plateau
28. West Torres Plateau
29. Manihiki Plateau
30. Pacific-Antarctic Ridge
31. Southeast Indian Ridge
32. Tasman Basin
33. Coral Sea Basin
34. Solomon Sea
35. Loyalty Basin
36. South Fiji Basin
37. D'Entrecasteaux Basin
38. Manus Basin
39. North Fiji Basin
40. Lau-Havre Basin
41. Woodlark Basin
42. Tasmantid hotspot
43. Tasmantid seamounts
44. Lord Howe hotspot
45. Lord Howe seamounts
46. Louisville hotspot
47. Louisville seamounts
48. Samoa hotspot
49. Samoan seamounts

Figure 1. Present-day locations of key tectonic elements and geologic provinces of the Southwest Pacific. 1-12=continental land masses and rifted continental margins; $13-25=$ island arcs and trenches; $26-29=$ oceanic plateaus; $30-31=$ ocean basin spreading centers; $32-41=$ dilational basins; $42-49=$ hotspot centers and associated trails.

alone. Between 7 and $10 \mathrm{Ma}$, Fiji was attached to the Vitiaz Arc (on the Pacific Plate) and the New Hebrides Arc closed against the Pacific Plate with a slight rotation.

Between 10 and $25 \mathrm{Ma}$, the Wewak-Trobriand (New Guinea) and the proto-Tonga-Kermadec (Lau-Colville) arcs are both attached directly to the Australia Plate.

Between 25 and $40 \mathrm{Ma}$, the Melanesian Arc (i.e., the Manus, North Solomon, and Vitiaz arcs) was tied to the Australia Plate, the
Vitiaz Arc by way of the northern South Fiji Basin (Minerva) spreading ridge. The island of 'Eua (with its associated ridge in the Tonga forearc) also closed against the Norfolk Ridge on the Australia Plate by way of the Minerva and the South Loyalty spreading ridges. The Three Kings-Northland New Zealand Arc (27-32 Ma) and the Three Kings trench-line (27-34 Ma) were rotated toward the Tonga Trench line (affixed to the northern end of New Zealand South Island on the Pacific Plate) by means of the southern South Fiji Basin (Kupe) 
Table 1. Rotation vectors determined for the Australian (AU) Plate from hotspot trails in the Tasman Sea and eastern Australia (Yan, 1988).

\begin{tabular}{crrr}
\hline \multirow{2}{*}{$\begin{array}{c}\text { Age } \\
(\mathrm{Ma})\end{array}$} & \multicolumn{2}{c}{ Pole of rotation } & $\begin{array}{c}\text { Angle } \\
\text { of rotation } \\
\text { (degree) }\end{array}$ \\
\cline { 2 - 3 } & Latitude & Longitude & \\
\hline $11.8-0$ & -18.80 & -148.30 & 8.60 \\
$16.4-11.8$ & -28.20 & -152.00 & 3.40 \\
$27.7-16.4$ & -10.80 & -157.80 & 8.40 \\
$43.0-27.7$ & -25.20 & -173.20 & 10.70 \\
$55.0-43.0$ & 14.40 & -65.80 & 8.00 \\
\hline
\end{tabular}

Table 2. Rotation vector determined for the India (IN) Plate from Ninetyeast Ridge (this study and Duncan, 1991).

\begin{tabular}{|c|c|c|c|}
\hline \multirow{2}{*}{$\begin{array}{l}\text { Age } \\
(\mathrm{Ma})\end{array}$} & \multicolumn{2}{|c|}{ Pole of rotation } & \multirow{2}{*}{$\begin{array}{c}\text { Angle } \\
\text { of rotation } \\
\text { (degree) }\end{array}$} \\
\hline & Latitude & Longitude & \\
\hline $85.0-55.0$ & 0.80 & 13.1 & -25.98 \\
\hline
\end{tabular}

Table 3. Rotation vector determined for the Antarctica (AN) Plate from the Kerguelen Plateau based on the assumption of an age progression along a straight line path collinear with the northern edge of the Kerguelen Plateau (this study).

\begin{tabular}{cccc}
\hline \multirow{2}{*}{$\begin{array}{c}\text { Age } \\
(\mathrm{Ma})\end{array}$} & \multicolumn{2}{c}{ Pole of rotation } & \multirow{2}{*}{$\begin{array}{c}\text { Angle } \\
\text { of rotation } \\
\text { (degree) }\end{array}$} \\
\cline { 2 - 3 } $100.0-85.0$ & 58.8 & 165.7 & -7.5 \\
\hline
\end{tabular}

Table 4. Total poles of rotation for the IndoAustralian (IA) Plate (this study).

\begin{tabular}{|c|c|c|c|}
\hline \multirow{2}{*}{$\begin{array}{l}\text { Age } \\
(\mathrm{Ma})\end{array}$} & \multicolumn{2}{|c|}{ Pole of rotation } & \multirow{2}{*}{$\begin{array}{c}\text { Angle } \\
\text { of rotation } \\
\text { (degree) }\end{array}$} \\
\hline & Latitude & Longitude & \\
\hline 11.8 & 18.80 & 31.70 & -8.60 \\
\hline 16.4 & 21.54 & 30.92 & -11.96 \\
\hline 27.7 & 17.52 & 26.73 & -20.22 \\
\hline 43.0 & 21.53 & 20.66 & -30.49 \\
\hline 55.0 & 13.94 & 34.61 & -30.34 \\
\hline 63.4 & 12.89 & 39.19 & -28.71 \\
\hline 67.7 & 11.22 & 47.10 & -27.70 \\
\hline 76.1 & 7.94 & 56.39 & -27.14 \\
\hline 84.0 & 6.03 & 51.07 & -30.43 \\
\hline 85.0 & 5.69 & 50.07 & -31.22 \\
\hline 96.0 & 7.03 & 59.12 & -34.29 \\
\hline 100.0 & 8.33 & 61.80 & -35.20 \\
\hline
\end{tabular}

spreading ridge. (This rotation prevents overlap of the Challenger Plateau by the New Zealand North Island prior to $55 \mathrm{Ma}$.) The Louisiade Plateau-Rennell Arc closed against the d'Entrecasteaux Fracture Zone at the northwestern end of New Caledonia by means of the d'Entrecasteaux Basin spreading ridge (27-34 Ma). On the western margin of the Pacific Plate, the Eauripik and Caroline ridges disappeared at $27 \mathrm{Ma}$ (in the vicinity of the Caroline hotspot) and the East and West Caroline basins closed to the north (27-34 Ma) along the western edge of the plate (Hegarty et al., 1983; Hegarty and Weissel, 1988).

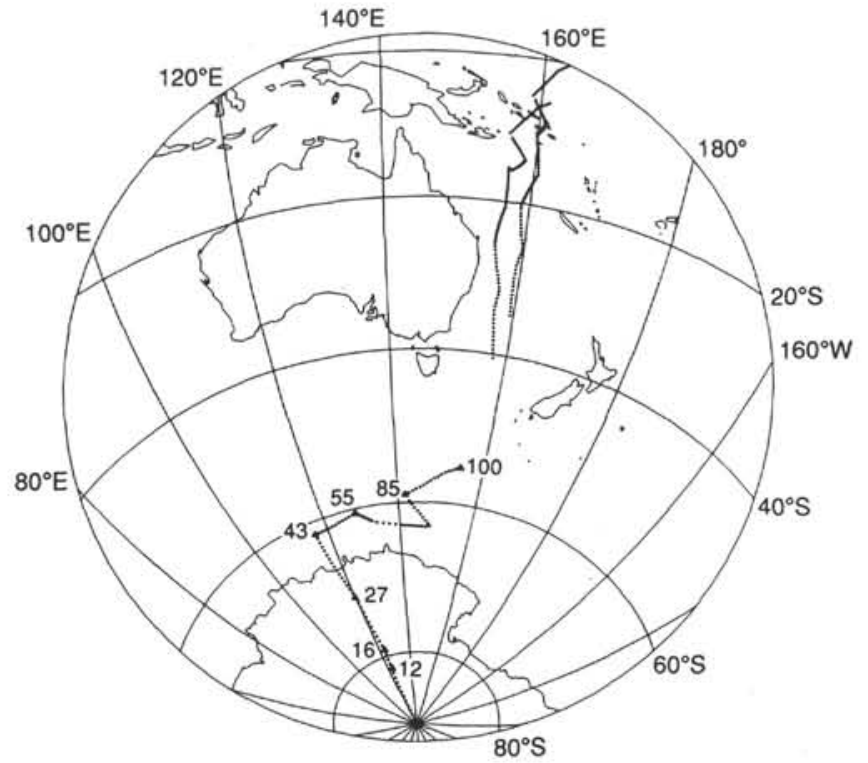

Figure 2. Computer-modeled tracks of the Tasmantid and Lord Howe hotspots on the Australia Plate and the Indo-Australia apparent polar wander path based on the rotation poles and angles for Australia Plate motion determined by Yan (1988) and this study.

Between 40 and $55 \mathrm{Ma}$, the Papuan (Aure-Moresby-Pocklington)-Rennell-New Caledonia-Norfolk arcs, up to this point attached to the Australia Plate, must now be tied to the Pacific Plate by way of dilational backarc basins (e.g., via the Solomon Sea and North Loyalty basins) for which scant information is available. To circumvent this problem, the Norfolk Ridge (and thus the Papuan-RennellNew Caledonia-Norfolk arc complex) was tied to the Australia Plate across a transform boundary along the western side of the Norfolk Ridge. The amount of displacement along this boundary, albeit unknown, has been conservatively estimated at $200 \mathrm{~km}$. Between 53 and $55 \mathrm{Ma}$, spreading was occurring, however, in the Coral Sea Basin, requiring an additional circuit joining the northern side of the basin to the Australia Plate by way of the Coral Sea spreading ridge.

Between 55 and $65 \mathrm{Ma}$, the New Caledonia-Norfolk ridges, the New Zealand North Island, the West Norfolk Ridge, and the Lord Howe Rise-Challenger Plateau were tied to Australia by way of the Tasman Basin spreading ridge. The northern side of the Coral Sea Basin was also joined to the Australia Plate by means of the Coral Sea spreading ridge from 55 to $63 \mathrm{Ma}$.

Between 65 and $74 \mathrm{Ma}$, the combined Lord Howe Rise-Challenger Plateau-New Zealand North Island were tied to Australia by way of the Tasman Basin spreading ridge. An additional circuit was used to join the Norfolk Ridge to the Australia Plate by way of both a New Caledonia spreading ridge and the Tasman Basin spreading ridge, closing first against the West Norfolk Ridge and next into juxtaposition with the Lord Howe Rise by $74 \mathrm{Ma}$.

Between 74 and $85 \mathrm{Ma}$, the combined Lord Howe Rise, Challenger Plateau, Norfolk Ridge, and New Zealand North Island are tied to Australia by way of the Tasman Basin spreading ridge, moving into juxtaposition with Australia by $85 \mathrm{Ma}$. Between 85 and $100 \mathrm{Ma}$, all of these features were joined directly to and moved with the Australia Plate. Some overlap occurred between the Challenger Plateau and East Antarctica between 74 and $100 \mathrm{Ma}$. This overlap probably could be suppressed or even prevented by changing the time of separation of the Challenger Plateau from the Lord Howe Rise and allowing more overlap with the New Zealand North Island (the shape of which has been retained only to facilitate recognition). 
Table 5. Rotation vectors determined for the Pacific Plate from the Hawaii-Emperor and Louisville hotspot trails (this study and Duncan and Clague, 1985).

\begin{tabular}{llrr}
\hline \multirow{2}{*}{$\begin{array}{c}\text { Age } \\
\text { (Ma) }\end{array}$} & \multicolumn{2}{c}{ Pole of rotation } & \multicolumn{1}{c}{$\begin{array}{c}\text { Angle } \\
\text { of rotation } \\
\text { (degree) }\end{array}$} \\
\cline { 2 - 3 } $23.6-0$ & 72.00 & 280.00 & 21.00 \\
$30.8-23.6$ & 55.60 & 296.75 & 4.74 \\
$43.0-30.8$ & 59.00 & 306.00 & 8.00 \\
$65.0-43.0$ & 15.29 & 254.80 & 14.00 \\
$74.0-65.0$ & 22.00 & 265.00 & 7.50 \\
\hline
\end{tabular}

Table 6. Rotation vectors determined for the Pacific Plate from the Musician Seamounts (this study and Pringle, 1992).

\begin{tabular}{|c|c|c|c|}
\hline \multirow{2}{*}{$\begin{array}{l}\text { Age } \\
\text { (Ma) }\end{array}$} & \multicolumn{2}{|c|}{ Pole of rotation } & \multirow{2}{*}{$\begin{array}{c}\text { Angle } \\
\text { of rotation } \\
\text { (degree) }\end{array}$} \\
\hline & Latitude & Longitude & \\
\hline $100.0-74.0$ & 18.90 & 319.5 & 13.38 \\
\hline
\end{tabular}

Table 7. Total poles of rotation for the Pacific Plate.

\begin{tabular}{|c|c|c|c|}
\hline \multirow{2}{*}{$\begin{array}{c}\text { Age } \\
(\mathrm{Ma})\end{array}$} & \multicolumn{2}{|c|}{ Pole of rotation } & \multirow{2}{*}{$\begin{array}{c}\text { Angle } \\
\text { of rotation } \\
\text { (degree) }\end{array}$} \\
\hline & Latitude & Longitude & \\
\hline 23.60 & 72.000 & -80.000 & 21.000 \\
\hline 30.80 & 69.466 & -73.652 & 25.553 \\
\hline 43.00 & 67.742 & -66.178 & 33.386 \\
\hline 65.00 & 52.375 & -79.290 & 42.427 \\
\hline 74.00 & 47.507 & -80.108 & 48.900 \\
\hline 100.00 & 46.168 & -66.729 & 59.345 \\
\hline
\end{tabular}

\section{Pacific-Antarctic Circuits}

Between 0 and $25 \mathrm{Ma}$, the Chatham Rise, Campbell Plateau, and most of the New Zealand South Island were tied to the Pacific Plate; this achieved the alignment proposed by Walcott (1987) for Chatham Rise-Campbell Plateau-New Zealand South Island with respect to Norfolk Ridge-New Zealand North Island-Challenger Plateau on the Australia Plate. Antarctica remained intact during this time, moving as an independent plate.

Between 25 and $43 \mathrm{Ma}$, Antarctica was broken into West and East Antarctica, with West Antarctica tied to the Pacific Plate by means of the Pacific-Antarctic Ridge, permitting closure back in time against the Campbell Plateau. As a consequence, West Antarctica overlapped East Antarctica during this time, indicating that divergence must have occurred (forward in time) between East and West Antarctica, as discussed by Dalziel (1992). This tie, however, eliminates the Norfolk Ridge-Chatham Rise alignment favored by Walcott (1987).

Between 43 and $85 \mathrm{Ma}$, the combined Chatham Rise-Campbell Plateau-New Zealand South Island was tied to West Antarctica by means of the Pacific-Antarctic Ridge with West Antarctica rejoined to East Antarctica. This tie permitted closure of the combined Chatham Rise-Campbell Plateau-New Zealand South Island against a reunited Antarctica using a pole of rotation determined by Mayes et al. (1990) for this part of the Pacific-Antarctic Ridge. Tying the two Antarcticas together backward in time at $43 \mathrm{Ma}$ also has the advantage of preventing West Antarctica from being pulled back from East Antarctica by Pacific Plate motion (which, forward in time, would indicate a considerable amount of unsubstantiated convergence along the Transantarctic Mountains). Likewise, the Campbell Plateau was prevented from overlapping the Tasman Basin

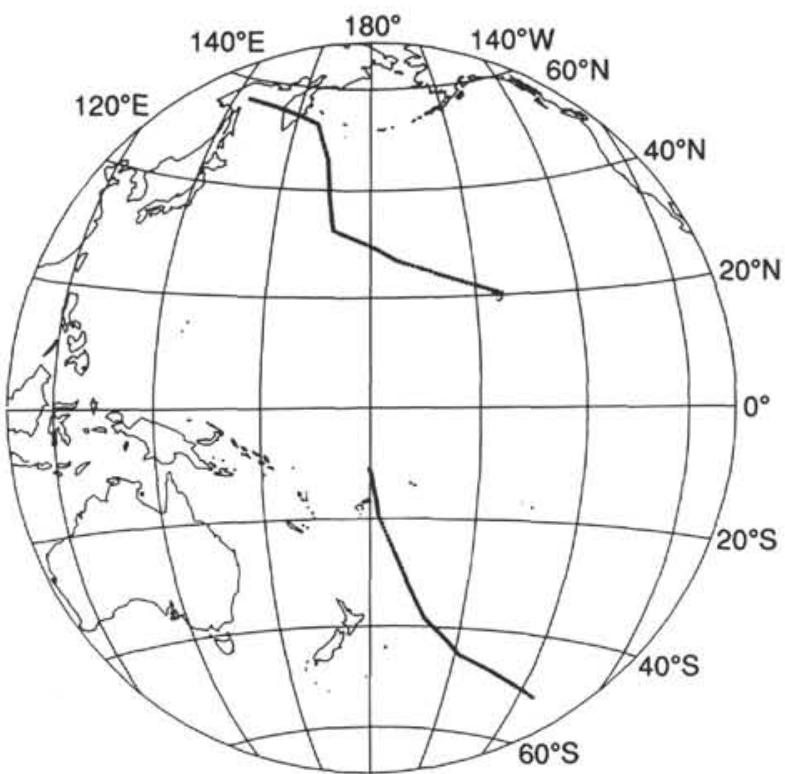

Figure 3. Computer-modeled tracks of the Hawaiian and Louisville hotspots on the Pacific Plate based on rotation poles and angles for Pacific Plate motion determined in this study for the time spans 0-65 and 74-100 Ma and the pole determined by Duncan and Clague (1985) for the time span 65-74 Ma.

magnetic anomalies. This model has the additional advantage of allowing continuous, uninterrupted spreading across the Pacific-Antarctic Ridge, as required by the continuous sequence of magnetic anomalies mapped by Cande et al. (1992) between the Campbell Plateau and Marie Byrd Land.

\section{PLATE RECONSTRUCTIONS}

Plate motions derived from the new poles and angles of rotation for the I-A and Pacific plates were used to reconstruct the location of tectonic elements and physiographic provinces of the Southwest Pacific for the past $100 \mathrm{~m}$.y. Using a modified version of the Fortran computer program designed by Morgan (1977), adapted to run on an IBM PC compatible, to plot the positions of continents and other plate features at various times in the past and using the poles and angles of rotation given in Tables 1-9, plate reconstructions were made by projecting plate motions through the plate circuits listed in Table 10. Shapes of the selected plate features shown in Figure 1 were plotted on a polar equal area projection at $0.5-\mathrm{m}$.y. intervals from 100 to $0 \mathrm{Ma}$. These plots are shown at the times of major tectonic events or changes in plate motion in Figure 4 and are discussed forward in time as tectonic events occurred. For reference, seamount chains are shown developing over key hotspots with the Louisville trail starting at 65 $\mathrm{Ma}$, the Tasmantid trail at $51 \mathrm{Ma}$, the Lord Howe trail at $35 \mathrm{Ma}$, and the Samoa trail at $14 \mathrm{Ma}$.

At approximately $100 \mathrm{Ma}$, a major change occurred in Pacific Plate motion. Subsequently, rom 100 to $85 \mathrm{Ma}$, the Ontong Java Plateau moved steadily northward with the Pacific Plate. During this time span, Australia with its attached eastern margin (including the Challenger Plateau, Lord Howe Rise, Norfolk Ridge, and New Zealand North Island); the combined Chatham Rise-Campbell PlateauNew Zealand South Island; and a pre-rift, proto-West Antarctica moved together in a roughly northeastward direction with the Antarctic Plate. Commencing at $96 \mathrm{Ma}$, an episode of slow spreading between Australia and Antarctica (Duncan and McDougall, 1989; Veevers and $\mathrm{Li}, 1991$ ) appears to have had an almost negligible effect on the trajectories of either plate.

At approximately $85 \mathrm{Ma}$, a major change in Australia-Antarctica plate motions occurred and spreading was initiated in the Tasman 
Table 8. Total/finite poles of rotation.

\begin{tabular}{lllll}
\hline & Time & & & \\
Chron & $(\mathrm{Ma})$ & Latitude & Longitude Angle & Reference \\
\hline
\end{tabular}

Australia/India-Antarctica (IA) relative to hotspot Circuit

Antarctica (AN55) relative to India (IN55):

\begin{tabular}{llrrrr} 
& $55.0-0$ & -2.5 & 9.2 & \multicolumn{1}{c}{0} & Royer and Sandwell (1989) \\
28 & $63.4-55.0$ & -2.5 & 9.2 & 10.01 & \\
31 & $67.7-63.4$ & -2.8 & -6.1 & 7.13 & \\
33 & $76.1-67.7$ & -2.9 & 3.4 & 10.95 & \\
34 & $84.0-76.1$ & -0.1 & 13.5 & 2.95 &
\end{tabular}

Australia (AU55) relative to Antarctica (AN55):

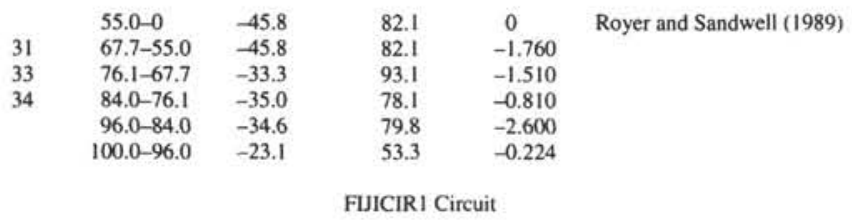

Norfolk Ridge (PU) relative to Indo-Australia (IA):

$\begin{array}{llll}40.0 & 19.0 & 297.0 & 0 \\ 53.0 & 19.0 & 297.0 & -3.50\end{array}$

South Loyalty Basin (LS) relative to Norfolk Ridge (PU):

$\begin{array}{llrrrr}18 & 40.6 & -5.08 & 212.07 & 0 & \text { Lapouille et al. (1982) } \\ 19 & 42.4 & -5.08 & 212.07 & -1.346 & \\ 20 & 43.9 & -5.08 & 212.07 & -3.006 & \\ 21 & 47.8 & -16.22 & 176.26 & -22.224 & \\ 22 & 50.4 & -16.14 & 176.25 & -29.224 & \\ 23 & 52.3 & -16.04 & 176.32 & -34.624 & \end{array}$

Northern South Fiji Basin (FN) relative to South Loyalty Basin (LS):

\begin{tabular}{rrrrrl} 
7A & 25.9 & -18.67 & 194.45 & 0 & $\begin{array}{l}\text { Malahoff et al. (1982) } \\
8\end{array}$ \\
\hline & 26.7 & -18.67 & 194.55 & 2.264 & (Minerva anomalies) \\
9 & 28.0 & -18.67 & 194.55 & 4.782 & and this study \\
10 & 29.3 & -18.67 & 194.55 & 6.520 & \\
I1 & 30.8 & -19.22 & 194.80 & 9.270 & \\
12 & 31.8 & -19.45 & 194.96 & 11.300 &
\end{tabular}

Pandora Bank (PZ) and eastern Minerva Basin (ME) relative to northem South Fiji Basin (FN):

$\begin{array}{rrrrrl}8 & 26.7 & -3.68 & 177.83 & 0 & \text { Malahoff et al. (1982) } \\ 9 & 28.0 & -3.68 & 177.83 & -0.781 & \text { (Minerva anomalies) } \\ 10 & 29.3 & -3.68 & 177.83 & -2.822 & \text { and this study } \\ 11 & 30.8 & -3.68 & 177.83 & -5.918 & \\ 12 & 31.8 & -3.68 & 177.83 & -7.783 & \end{array}$

Northwestern North Fiji Basin (F0) relative to Pandora Bank (PZ):

$$
\begin{array}{lllll}
0.4 & -19.10 & 148.70 & 1.0 & \text { This study }
\end{array}
$$

Southwestern North Fiji Basin (F1) relative to northwestern North Fiji Basin (F0):

$\begin{array}{lrrrrl} & 1.2 & -10.13 & 163.64 & 0 & \begin{array}{l}\text { Malahoff et al. (in press) } \\ \text { (North Fiji anomalies) }\end{array} \\ 2 \mathrm{~A} & 1.8 & -10.13 & 163.64 & 2.49 & \text { and this study } \\ 3 & 2.9 & -10.13 & 163.64 & 5.35 & \\ 3 \mathrm{~A} & 4.5 & -10.13 & 163.64 & 9.33 & \\ 4 & 6.0 & -10.13 & 163.64 & 15.75 & \\ & 7.3 & -10.13 & 163.64 & 24.69 & \\ & 10.0 & -10.13 & 163.64 & 40.10 & \text { CLOSURE }\end{array}$

Eastern North Fiji Basin (FC) relative to southwestern North Fiji Basin (F1):

$\begin{array}{lrrrrl}\mathrm{J} & 0.9 & -15.00 & 173.10 & -7.22 & \text { Malahoff et al. (in press) } \\ 2 & 1.8 & 15.00 & 172.19 & -2.01 & \text { (North Fiji anomalies) } \\ 2 \mathrm{~A} & 2.9 & 15.70 & 171.68 & -3.06 & \text { and this study } \\ 3 & 4.5 & -15.29 & 172.97 & -25.72 & \\ 3 \mathrm{~A} & 6.0 & -15.50 & 172.80 & -33.08 & \end{array}$

\begin{tabular}{ccccc}
\hline Chron & $\begin{array}{l}\text { Time } \\
(\mathrm{Ma})\end{array}$ & Latitude & Longitude Angle & Reference \\
\hline & FUICIR2 Circuit
\end{tabular}

Fiji Islands (FI) relative to eastern North Fiji Basin (FC) with FI-F0 stopped at $7.9 \mathrm{Ma}$ :

$$
\begin{array}{cccc}
1.5 & -40.00 & 185.00 & 4.50 \quad \text { Jarvis }(1991) \text { and this study } \\
\text { PACl Circuit }
\end{array}
$$

Southern Bismarck (BS) relative to Norfolk Ridge (PU):

$\begin{array}{lrrrrl}2 & 1.8 & -20.90 & 140.58 & 2.35 & \text { Taylor (1979) } \\ 2 \mathrm{~A} & 2.9 & -20.90 & 140.58 & 3.51 & \text { (Manus anomalies) } \\ 3 & 4.5 & -20.90 & 140.58 & 5.33 & \text { and this study } \\ & 6.0 & -20.90 & 140.58 & 13.00 & \\ & 30.0 & -20.90 & 140.58 & 13.00 & \end{array}$

Bismarck Rotation (BR) relative to southem Bismarck (BS):

$$
\begin{array}{rrrrr}
4.0 & -4.51 & 152.29 & 0 & \text { This study } \\
30.0 & -4.51 & 152.29 & -30.0 & \\
\\
\text { PAC2 Circuit }
\end{array}
$$

South Pandora Ridge $(\mathrm{FH})$ relative to $\mathrm{P}$ :

$$
\begin{array}{ccc}
0.4 & -19.10 & 148.70 \\
\text { PAC4 Circuit }
\end{array}
$$

Southern East Caroline Basin (CS) relative to Pacific (P4):

$\begin{array}{rrrrr}8 & 26.7 & 19.70 & 245.86 & 0 \\ 9 & 28.0 & 19.70 & 245.86 & -0.400 \\ 10 & 29.3 & 19.70 & 245.86 & -1.269 \\ 11 & 30.8 & 19.70 & 245.86 & -3.017 \\ 12 & 31.8 & 19.70 & 245.86 & -4.668 \\ 13 & 34.5 & 19.70 & 245.86 & -7.402\end{array}$

PAC5 Circuit

Southern West Caroline Basin (CZ) relative to Pacific (P4):

$\begin{array}{rrrrrl}9 & 28.0 & 13.00 & 248.04 & 0 & \text { Hegarty and Weissel (1988) } \\ 10 & 29.3 & 13.00 & 248.04 & -1.933 & \text { and this study } \\ 11 & 30.8 & 13.00 & 248.04 & -3.594 & \\ 12 & 31.8 & 13.00 & 248.04 & -4.590 & \\ 13 & 34.5 & 13.00 & 248.04 & -6.230 & \\ & & & \\ & & & \end{array}$

Fiji Islands (Vanua Levu) (FM) relative to Pacific (P3):

$$
\begin{array}{ccccc}
0.4 & -19.10 & 148.70 & 1.0 & \text { This study } \\
& \text { SFIJI Circuit }
\end{array}
$$

Southern Dampier Ridge (TM) relative to Indo-Australia (IA):

\begin{tabular}{llrlrr}
24 & 53.4 & -4.5 & 140.0 & 0 & Shaw (1979), Table 2-2 \\
26 & 58.8 & -4.5 & 140.0 & -2.65 & \\
27 & 61.6 & -8.0 & 142.5 & -5.00 & \\
29 & 64.2 & -11.0 & 143.2 & -7.50 & -9.50 \\
30 & 65.4 & -12.0 & 143.0 & -11.20 \\
31 & 67.2 & -13.5 & 143.0 & -11.20 \\
\multicolumn{5}{c}{ SFIII Circuit }
\end{tabular}

Eastern Tasman Basin (TE) relative to Indo-Australia (IA):

$\begin{array}{llrrrr}24 & 53.4 & -4.5 & 140.0 & 0 & \text { Shaw (1979), Table 2-2 } \\ 26 & 58.8 & -4.5 & 140.0 & -2.65 & \\ 27 & 61.6 & -8.0 & 142.5 & -5.00 & \\ 29 & 64.2 & -11.0 & 143.2 & -7.50 & \\ 30 & 65.4 & -12.0 & 143.0 & -9.50 & \\ 31 & 67.2 & -13.5 & 143.0 & -11.20 \\ 32 & 70.1 & -18.0 & 145.5 & -17.00 \\ 33 & 79.1 & -16.5 & 143.5 & -20.50 & \\ & 84.0 & -16.5 & 143.5 & -22.00\end{array}$


Table 8 (continued).

\begin{tabular}{lllll}
\hline Chron & $\begin{array}{l}\text { Time } \\
(\mathrm{Ma})\end{array} \quad$ Latitude Longitude Angle & Reference \\
\hline
\end{tabular}

Norfolk Transform Line (NF) relative to eastern Tasman Basin (TE):

$\begin{array}{lllcl}65.0 & -13.0 & 140.0 & 0 & \text { This study } \\ 68.4 & -13.0 & 140.0 & -3.0 & \end{array}$

New Caledonia (NC) relative to Norfolk Transform Line (NF):

$\begin{array}{lllcl}40.0 & 19.0 & 297.0 & 0 & \text { This study } \\ 53.0 & 19.0 & 297.0 & -3.50 & \end{array}$

Norfolk Ridge (PU) relative to New Caledonia (NC):

$\begin{array}{lllcl}65.0 & -13.0 & 140.0 & 0 & \text { This study } \\ 74.0 & -13.0 & 140.0 & -5.0 & \end{array}$

Eastem South Fiji Basin (FE) relative to northem South Fiji Basin (FN):

\begin{tabular}{|c|c|c|c|c|c|}
\hline & 25.2 & -3.92 & 184.90 & 0 & Malahoff et al. (1982) \\
\hline $7 \mathrm{~A}$ & 25.9 & -3.92 & 184.90 & -1.152 & (Minerva anomalies) \\
\hline 8 & 26.7 & -3.92 & 184.90 & -1.425 & and this study \\
\hline 9 & 28.0 & -3.15 & 185.43 & -3.027 & \\
\hline 10 & 29.3 & -3.15 & 185.43 & -4.810 & \\
\hline II & 30.8 & -3.15 & 185.43 & -7.109 & \\
\hline 12 & 31.8 & -3.15 & 185.43 & -8.740 & \\
\hline
\end{tabular}

Eastern Lau Basin (LE) relative to eastern Minerva Basin (ME):

$\begin{array}{lllll}\text { J } & 0.9 & -34.0 & 181.5 & 2.18 \\ 2 & 1.8 & -34.0 & 181.5 & 4.77 \\ 2 \mathrm{~A} & 2.9 & -34.0 & 181.5 & 6.56 \\ 3 & 4.5 & -34.0 & 181.5 & 8.56 \\ 3 \mathrm{~A} & 6.0 & -34.0 & 181.5 & 12.16 \\ & 7.0 & -34.0 & 181.5 & 15.00\end{array}$

'Eua (A6) relative to eastern Lau Basin (LE):

$$
\begin{array}{lcccc}
31.8 & 10.0 & 185.0 & 0 & \text { This study } \\
42.0 & 10.0 & 185.0 & -25.0 & \\
& \multicolumn{3}{c}{\text { SFUI3 Circuit }}
\end{array}
$$

Three Kings Line (HS) relative to Norfolk Ridge (PU):

$\begin{array}{rrrrr}8 & 26.7 & -41.5 & 164.0 & 0 \\ 9 & 28.0 & -41.5 & 164.0 & -3.40 \\ 10 & 29.3 & -41.5 & 164.0 & -9.00 \\ 11 & 30.8 & -41.5 & 164.0 & -12.60 \\ 13 & 34.5 & -41.5 & 164.0 & -21.66\end{array}$

SFU14 Circuit

New Zealand (NZ) relative to Eastern Tasman Basin (TE):

$\begin{array}{rrrrr}8 & 26.7 & -41.5 & 164.0 & 0 \\ 9 & 28.0 & -41.5 & 164.0 & -3.40 \\ 10 & 29.3 & -41.5 & 164.0 & -9.00 \\ 11 & 30.8 & -41.5 & 164.0 & -12.60 \\ 13 & 34.5 & -41.5 & 164.0 & -21.66\end{array}$

Eastern Havre Trough (HE) relative to New Zealand (NZ):

$\begin{array}{llllll}\text { J } & 0.9 & -44.42 & 170.90 & 0.937 & \text { Malahoff et al. (1982) } \\ 2 & 1.8 & -44.42 & 170.90 & 1.890 & \text { (Havre anomalies) } \\ & 2.9 & -44.42 & 170.90 & 4.000 & \text { and this study }\end{array}$

Malahoff et al. (1982)

(Kupe anomalies)

and this study

(Kupe anomalies)

and this study

\begin{tabular}{lllll}
\hline Chron & $\begin{array}{l}\text { Time } \\
(\mathrm{Ma})\end{array}$ & Latitude & Longitude Angle & Reference \\
\hline & AUSTI Circuit \\
Northern Woodlark (WN) relative to New Guinea Overthrust (ZU) and Norfolk Ridge (PU):
\end{tabular}

$\begin{array}{llllll}\mathrm{J} & 0.9 & -9.31 & 137.58 & -1.80 & \text { Taylor (1987) } \\ 2 & 1.8 & -9.31 & 137.58 & -3.50 & \text { (Woodlark anomalies) } \\ 2 \mathrm{~A} & 2.9 & -9.45 & 137.25 & -6.50 & \text { and this study } \\ & 4.5 & -9.45 & 137.25 & -6.77 & \end{array}$

Woodlark Rotation, western end (WR) relative to northern Woodlark (WN):

$$
\begin{array}{lllll}
27.8 & -8.67 & 153.51 & 0 & \text { This study } \\
31.8 & -8.67 & 153.51 & -35.0 & \\
& \multicolumn{3}{c}{\text { AUST2 Circuit }}
\end{array}
$$

New Guinea Trench line (WM) relative to New Guinea Overthrust (ZU) and Norfolk Ridge (PU):

$$
\begin{array}{rrrrr}
0.9 & 3.0 & 57.0 & -0.47 & \text { This study } \\
1.8 & -5.0 & 91.0 & -1.07 & \\
& \text { AUST3 Circuit }
\end{array}
$$

Northern South Rennell Trough (RN) relative to New Guinea Overthrust (ZU) and Norfolk Ridge (PU)

\begin{tabular}{rrrrrl}
8 & 26.7 & -39.0 & 105.12 & 0 & Larue et al. (1977) \\
9 & 28.0 & -39.0 & 105.12 & -0.91 & (South Rennell anomalies) \\
10 & 29.3 & -39.2 & 105.12 & -1.70 & and this study \\
& 31.8 & -39.2 & 105.12 & -2.27 & \\
& 36.0 & -39.2 & 105.12 & -4.65 & \\
& & \multicolumn{3}{c}{ LOUISIADE Circuit }
\end{tabular}

Louisiade Plateau (LA) relative to Indo-Australia (1A):

$\begin{array}{rrrrrl}8 & 26.7 & -39.0 & 105.12 & 0 & \text { Larue et al. (1977) } \\ 9 & 28.0 & -39.0 & 105.12 & -0.91 & \text { (South Rennell anomalies) } \\ 10 & 29.3 & -39.2 & 105.12 & -1.70 & \text { and this study } \\ & 31.8 & -39.2 & 105.12 & -2.27 & \\ & 36.0 & -39.2 & 105.12 & -4.65 & \end{array}$

NEW GUINEA Circuit

Northem Coral Sea Basin (ZN) relative to Indo-Australia (IA):

$\begin{array}{lrrrrr}24 & 54.0 & -1.0 & 127.0 & 0 & \text { Shaw (1979) } \\ 25 & 57.5 & -1.0 & 127.0 & -2.5 & \\ 26 & 59.1 & -1.0 & 127.0 & -3.7 & \\ 27 & 61.9 & -11.0 & 141.0 & -13.0 & \\ & 65.0 & -11.0 & 141.0 & -15.0 & \text { CLOSURE }\end{array}$

New Guinea Overthrust (NG) relative to northem Coral Sea Basin (ZN):

$$
\begin{array}{ccccc}
40.0 & 19.0 & 297.0 & 0 & \text { This study } \\
53.0 & 19.0 & 297.0 & -3.50 & \\
\\
\text { Southeastem SOLOMON BASIN Rotation Circuit }
\end{array}
$$

Southeastern Solomon Basin Rotation (AR) relative to northern Coral Sea Basin (ZN):

$$
\begin{array}{ccccc}
27.8 & -12.05 & 154.67 & 0 & \text { This study } \\
31.8 & -12.05 & 154.67 & -35.0 & \\
\multicolumn{5}{c}{\text { Southeastern WOODLARK BASIN Rotation Circuit }}
\end{array}
$$

Southeastern Woodlark Basin Rotation (RU) relative to Indo-Australia (IA):

$\begin{array}{lllcc}40.0 & 19.0 & 297.0 & 0 & \text { This study } \\ 53.0 & 19.0 & 297.0 & -3.50 & \end{array}$


Table 8 (continued).

\begin{tabular}{llllll}
\hline Chron & $\begin{array}{l}\text { Time } \\
(\mathrm{Ma})\end{array}$ & Latitude & Longitude & Angle & Reference \\
\hline Southern PACIFIC-ANTARCTIC RIDGE and Northern PACIFIC-ANTARCTIC RIDGE
\end{tabular}
Circuits

Southern Pacific-Antarctic Ridge (AB) relative to Pacific (PA):

\begin{tabular}{|c|c|c|c|c|}
\hline $4.5-0$ & 66.200 & -83.500 & -4.130 & Mayes et al. (1990) \\
\hline $9.7-4.5$ & 73.642 & -72.381 & -5.014 & \\
\hline $25.2-9.7$ & 74.873 & -63.881 & -10.429 & \\
\hline $29.3-25.2$ & 75.090 & -45.398 & -3.023 & \\
\hline $34.5-29.3$ & 71.284 & -49.940 & -4.182 & \\
\hline $40.6-34.5$ & 64.878 & -61.893 & -3.245 & \\
\hline $47.8-40.6$ & 66.502 & -61.086 & -4.062 & \\
\hline $57.5-47.8$ & 50.967 & -73.311 & -3.036 & \\
\hline $63.4-57.5$ & 51.103 & -73.359 & -3.289 & \\
\hline $67.7-63.4$ & 54.460 & -69.266 & -4.787 & \\
\hline $84.0-67.7$ & 54.525 & -69.269 & -8.748 & \\
\hline
\end{tabular}

Campbell (PC) relative to $\mathrm{P}$ :

$\begin{array}{lllll} & 43.0-0 & 66.502 & -61.086 & 0 \\ 21 & 47.8-43.0 & 66.502 & -61.086 & 2.710 \\ 25 & 57.5-47.8 & 50.967 & -73.311 & 3.036 \\ 28 & 63.4-57.5 & 51.103 & -73.359 & 3.289 \\ 31 & 67.7-63.4 & 54.460 & -69.266 & 4.787 \\ 32 & 84.0-67.7 & 54.525 & -69.269 & 8.748\end{array}$

ANTARCTICA-WEST ANTARCTICA Circuit

Antarctica (AN) relative to Australia (AU):

$\begin{array}{crrrr}9.7-0 & 12.5 & 36.7 & 6.620 & \text { Royer and Sandwell (1989) } \\ 19.7-9.7 & 16.4 & 27.7 & 5.400 & \\ 34.5-19.7 & 11.8 & 32.8 & 8.430 & \\ 40.6-34.5 & 30.1 & 7.7 & 3.590 & \\ 43.9-40.6 & -11.2 & 65.3 & 1.220 & \\ 54.0-43.9 & -39.0 & 54.1 & 1.350 & \\ 55.0-54.0 & -45.8 & 82.1 & 0.139 & \end{array}$

Pacific (PA) relative to hotspot from 25 to $43 \mathrm{Ma}$ :

$\begin{array}{llll}25.0-0 & 55.60 & 296.75 & 0 \\ 30.8-25.0 & 55.60 & 296.75 & 3.82 \\ 43.0-30.8 & 59.00 & 306.00 & 8.00\end{array}$

West Antarctica (WA) relative to Pacific (PA) from 25 to $43 \mathrm{Ma}$ :

$\begin{array}{lllcc}25.0-0 & 74.873 & -63.881 & 0 & \text { Mayes et al. (1990) } \\ 25.2-25.0 & 74.873 & -63.881 & -0.135 & \\ 29.3-25.2 & 75.090 & -45.398 & -3.023 & \\ 34.5-29.3 & 71.284 & -49.940 & -4.182 & \\ 40.6-34.5 & 64.878 & -61.893 & -3.245 & \\ 43.0-40.6 & 66.502 & -61.086 & -1.354 & \end{array}$

Basin and in the Southwest Pacific Basin, south of the Campbell Plateau (Cande et al., 1989).

From 85 to $74 \mathrm{Ma}$, the Ontong Java Plateau continued to move steadily northward with the Pacific Plate while slow separation occurred between Australia and Antarctica, as both plates moved northward (centered along longitude $120^{\circ} \mathrm{E}$ ), roughly paralleling Pacific Plate motion. At the same time, the combined Challenger Plateau, Lord Howe Rise, Norfolk Ridge, and New Zealand North Island slowly separated from Australia, moving toward the northeast while the combined Chatham Rise, Campbell Plateau, and New Zealand South Island slowly separated from Antarctica along the Pacific-Antarctic Ridge and moved northward, probably decoupled from the Pacific Plate across the Eltanin and Udintsev fracture zones.

At approximately $74 \mathrm{Ma}$, a change occurred in Pacific Plate motion and spreading began in the New Caledonia Basin (Kroenke, 1984). From 74 to $65 \mathrm{Ma}$, the Ontong Java Plateau moved rapidly northward with the Pacific Plate as Australia and Antarctica continued to slowly separate while rotating, almost in place, in a counterclockwise fashion. During this time span, the Challenger Plateau, Lord Howe Rise, Norfolk Ridge, and New Zealand North Island rapidly
Table 9. Stage poles for Pacific and Indo-Australia plate motion used in the plate circuits given in Table 10.

\begin{tabular}{|c|c|c|c|c|c|}
\hline $\begin{array}{l}\text { Rotation } \\
\text { parameter }\end{array}$ & $\begin{array}{l}\text { Time } \\
\text { (Ma) }\end{array}$ & Latitude & Longitude & Angle & Reference \\
\hline \multirow[t]{7}{*}{ P1 } & $23.6-0$ & 72.00 & 280.00 & 21.00 & \multirow[t]{7}{*}{ This study } \\
\hline & $25.0-23.6$ & 55.60 & 296.75 & 0.92 & \\
\hline & $27.7-25.0$ & -10.80 & -157.80 & 2.01 & \\
\hline & $43.0-27.7$ & -25.20 & -173.20 & 10.70 & \\
\hline & $55.0-43.0$ & 14.40 & -65.80 & 8.00 & \\
\hline & $85.0-55.0$ & 0.80 & 13.10 & -25.98 & \\
\hline & $100.0-85.0$ & 58.80 & 165.70 & -7.50 & \\
\hline \multirow[t]{8}{*}{$\mathrm{P} 2$} & $23.6-0.0$ & 72.00 & 280.00 & 21.00 & \multirow[t]{8}{*}{ This study } \\
\hline & $25.0-23.6$ & 55.60 & 296.75 & 0.92 & \\
\hline & $27.7-25.0$ & -10.80 & -157.80 & 2.01 & \\
\hline & $40.0-27.7$ & -25.20 & -173.20 & 8.60 & \\
\hline & $43.0-40.0$ & 59.00 & 306.00 & 1.97 & \\
\hline & $65.0-43.0$ & 15.29 & 254.80 & 14.00 & \\
\hline & $74.0-65.0$ & 22.00 & -95.00 & 7.50 & \\
\hline & $100.0-74.0$ & 18.90 & 319.50 & 13.38 & \\
\hline \multirow[t]{8}{*}{ P3 } & $4.0-0$ & 35.61 & -131.62 & 2.01 & \multirow[t]{8}{*}{ This study } \\
\hline & $23.6-4.0$ & 72.00 & 280.00 & 17.44 & \\
\hline & $25.0-23.6$ & 55.60 & 296.75 & 0.92 & \\
\hline & $27.7-25.0$ & -10.80 & -157.80 & 2.01 & \\
\hline & $43.0-27.7$ & -25.20 & -173.20 & 10.70 & \\
\hline & $55.0-43.0$ & 14.40 & -65.80 & 8.00 & \\
\hline & $85.0-55.0$ & 0.80 & 13.10 & -25.98 & \\
\hline & $100.0-85.0$ & 58.80 & 165.70 & -7.50 & \\
\hline \multirow[t]{8}{*}{ P4 } & $10.0-0$ & -18.80 & -148.30 & 7.29 & \multirow[t]{8}{*}{ This study } \\
\hline & $23.6-10.0$ & 72.00 & 280.00 & 12.10 & \\
\hline & $25.0-23.6$ & 55.60 & 296.75 & 0.92 & \\
\hline & $27.7-25.0$ & -10.80 & -157.80 & 2.00 & \\
\hline & $43.0-27.7$ & -25.20 & -173.20 & 10.70 & \\
\hline & $55.0-43.0$ & 14.40 & -65.80 & 8.00 & \\
\hline & $85.0-55.0$ & 0.80 & 13.10 & -25.98 & \\
\hline & $100.0-85.0$ & 58.80 & 165.70 & -7.50 & \\
\hline \multirow[t]{6}{*}{ P5 } & $23.6-0$ & 72.00 & 280.00 & 21.00 & \multirow[t]{6}{*}{ This study } \\
\hline & $30.8-23.6$ & 55.60 & 296.75 & 4.74 & \\
\hline & $43.0-30.8$ & 59.00 & 306.00 & 8.00 & \\
\hline & $55.0-43.0$ & 14.40 & -65.80 & 8.00 & \\
\hline & $85.0-55.0$ & 0.80 & 13.10 & -25.98 & \\
\hline & $100.0-85.0$ & 58.80 & 165.70 & -7.50 & \\
\hline
\end{tabular}

separated from Australia, as fast spreading developed in the Tasman Basin. This episode of fast spreading in the Tasman Basin caused the rapid displacement of the Lord Howe Rise to the northeast, whereas the spreading that ensued in the New Caledonia Basin caused an even more rapid displacement of the joined Norfolk Ridge-New Zealand North Island-Challenger Plateau to the north roughly paralleling the trajectory of the Pacific Plate. At the same time, the combined Chatham Rise-Campbell Plateau-New Zealand South Island rapidly separated from Antarctica as fast spreading also developed in the Southwest Pacific Basin south of the Campbell Plateau, causing this fragment to move northward, roughly paralleling, but still decoupled from, the motion of the Pacific Plate.

At $65 \mathrm{Ma}$, a change occurred in Pacific Plate motion and spreading ended in the New Caledonia Basin. From 65 to $55 \mathrm{Ma}$, the Ontong Java Plateau continued to rapidly move northward with the Pacific Plate and Australia and Antarctica continued to slowly separate as dilation continued in the Tasman Basin. During this time span, spreading also began in the Coral Sea Basin (about $63 \mathrm{Ma}$ ).

At approximately $55 \mathrm{Ma}$, a major change occurred in I-A Plate motion as spreading ended in the Tasman Basin and subduction began along the Papuan (Aure-Moresby-Pocklington)-New CaledoniaNorfolk trench system. From 55 to $40 \mathrm{Ma}$, northward subduction occurred beneath the Papuan, Rennell-New Caledonia, and Norfolk arcs. At this time, 'Eua and a portion of the modern Tonga forearc were attached to the eastern end of the New Caledonia Arc. Convergence was accommodated by long transform faults along the juxta- 
posed South Rennell-d'Entrecasteaux fracture zones and the western side of the Norfolk Ridge. Presumably, the southeastern end of the Norfolk Ridge was also connected to the Pacific-Antarctic Ridge, south of the southern tip of the Campbell Plateau, by a long transform fault that formed earlier during the opening of the Tasman Sea and now accommodated the northward translation of the combined Chatham Rise-Campbell Plateau-New Zealand South Island.

During this time span, basin dilation occurred within the backarc reaches north of the New Caledonia-Norfolk ridges (along the southern margin of the Pacific Plate), as evidenced by the Eocene magnetic anomaly lineations (52-40 Ma) that occurred in the Loyalty basins. By $53 \mathrm{Ma}$, however, spreading had ended in the Coral Sea Basin. From 48 to $43 \mathrm{Ma}$, the Louisiade Plateau apparently formed over the Lord Howe hotspot. At 43 Ma, a major change occurred in Pacific and I-A plate motions and southward subduction began along the Melanesian (Manus-North Solomon Island-Vitiaz) Trench. At 41 Ma, 'Eua became detached from the Norfolk Ridge and began to move eastward into the South Fiji Basin, driven by ongoing Loyalty Basin spreading.

At $40 \mathrm{Ma}$, subduction ended along the Papuan-Rennell-New Caledonia-Norfolk trench system ${ }^{5}$ as Melanesian Arc volcanism began. From 40 to $25 \mathrm{Ma}$, convergence continued along the Melanesian Trench, with the eastern end (i.e., the eastern end of the Vitiaz Trench) presumably connected by a long transform fault to the Pacific-Antarctic Ridge south of the southern tip of the Campbell Plateau. This transform fault probably also accommodated the northward translation of the combined Chatham Rise-Campbell PlateauNew Zealand South Island into juxtaposition with the Challenger Plateau. This same transform fault probably also provided the zone of weakness that controlled the subsequent formation of the protoTonga-Kermadec Trench. At $27 \mathrm{Ma}$, a change occurred in I-A Plate motion that coincided with the onset of subduction along the protoTonga-Kermadec and New Guinea (Wewak-Trobriand) trenches.

During this same time span, Three Kings subduction and arc volcanism (Kroenke and Eade, 1982; Eade, unpubl. data) also began (about 34 and $32 \mathrm{Ma}$, respectively) and basin dilation occurred in the East and West Caroline basins (34-27 Ma) along the western margin of the Pacific Plate as well as in the Solomon Sea (34-28 Ma), d'Entrecasteaux (34-28 Ma), Loyalty, and South Fiji (34-27 Ma) basins, then situated in the backarc reaches south of the Melanesian Arc. Spreading in the Caroline basins culminated in the formation of the Eauripik and Caroline ridges over the Caroline hotspot, whereas spreading in the d'Entrecasteaux Basin resulted in a westward displacement of the Louisiade Plateau. Spreading in the South Fiji Basin, presumed to be continuous with spreading in the Loyalty basins, caused the northward displacement of the Vitiaz segment of the Melanesian Arc and the continued eastward displacement of 'Eua across the South Fiji Basin into the proto-Tonga forearc.

At $25 \mathrm{Ma}$, after changes in I-A and Pacific plate motion occurred (27-23 Ma), subduction ended along the Melanesian and Three Kings trenches, spreading ended in the South Fiji Basin, and volcanism began along the Lau-Colville (proto-Tonga-Kermadec) Arc. From 25 to $10 \mathrm{Ma}$, convergent motion was accommodated along the WewakTrobriand trenches and the proto-Tonga-Kermadec Trench, presumably joined by a long transform fault that extended from the northeastern end of the Trobriand Trench to the northern end of the proto-Tonga Trench. Except for spreading along the Southeast Indian and Pacific-Antarctic ridges during this time span, basin dilation does not appear to have occurred in the region. At $12 \mathrm{Ma}$, I-A Plate motion

\footnotetext{
${ }^{5}$ This subduction zone and those that formed later constitute enduring zones of weakness that have been and can be periodically reactivated in response to changes in the stress field produced by collision and changes in plate motion. Despite these subsequent brief periods of reactivation, however, the primary subduction episode probably ended here at $40 \mathrm{Ma}$.
}

Table 10. Plate circuits used in the reconstruction with plate names in small letters indicating the chosen plate rotation parameters.

P1-IN55-AN55-AU55-PU-LS-FN-pz/ME-f0-f1-fc P1-IN55-AN55-AU55-PU-LS-FN-ME-F0-FI-FC-fi P1-IN55-AN55-AU55-PU-LS-FN-ME-fq(f1) $\mathrm{P} 2$-fh

P3-fm

P4-IN55-AN55-AU55-oj/PU-bs-br

P4-cs

P4-cz

P5-AU(43-55)-IN(55-84)-AN(43-84)-pc

PA-ab

IA-tm

IA-te-nf-nc-pu-Is-fn-fe

IA-TE-NF-NC-PU-LS-FN-me-le-a6

LA-TE-NF-NC-PU-hs

IA-TE-nz/HS-he

IA-zu-wn-wr

IA-ZU-wm

IA-ZU-m

IA-la

IA-ZN-ng

IA-zn-ar

IA-ru

AU/IN-IN43-an(0-43)-PA(25-43)-wa

Notes: Plate name abbreviations:

$\mathrm{A} 6={ }^{\prime}$ 'Eua

$\mathrm{AB}=$ southern Pacific - Antarctic Ridge

$\mathrm{AN}=$ Antarctica

$\mathrm{AR}=$ southeastern Solomon Basin Rotation

$\mathrm{AU}=$ Australia

$\mathrm{BR}=$ Bismarck Rotation

$\mathrm{BS}=$ southern Bismarck

$\mathrm{CS}=$ southern East Caroline Basin

$\mathrm{CZ}=$ southem West Caroline Basin

F0 $=$ northwestern North Fiji Basin

$\mathrm{F} 1=$ southwestern North Fiji Basin

$\mathrm{FC}=$ eastern North Fiji Basin

$\mathrm{FE}=$ eastern South Fiji Basin

$\mathrm{FH}=$ South Pandora Ridge

$\mathrm{FI}=$ Fiji Islands (Viti Levu)

FM = Fiji Islands (Vanua Levu)

$\mathrm{FN}=$ northern South Fiji Basin

$\mathrm{FQ}=$ northern New Hebrides

$\mathrm{HE}=$ eastern Havre Trough

HS $=$ Three Kings Line (Kupe Basin)

$\mathrm{IA}=$ Indo-Australia

IN $=$ India

$\mathrm{LA}=$ Louisiade

$\mathrm{LE}=$ eastem Lau Basin

LS $=$ South Loyalty Basin

$\mathrm{ME}=$ eastern Minerva Basin

$\mathrm{NC}=$ New Caledonia

$\mathrm{NF}=$ Norfolk Transform Line

$\mathrm{NG}=$ New Guinea Overthrust

$\mathrm{NZ}=$ New Zealand North Island

$\mathrm{OJ}=$ Ontong Java Plateau (with 0-4.0 Ma overthrust)

$\mathrm{P} 1=$ Pacific $\mathrm{I}-\mathrm{A}$ combination

P2 = Pacific I-A combination

$\mathrm{P} 3=$ Pacific $\mathrm{I}-\mathrm{A}$ combination

$\mathrm{P} 4=$ Pacific I-A combination

P5 = Pacific I-A combination

$\mathrm{PA}=$ Pacific

$\mathrm{PC}=$ Campbell Plateau

$\mathrm{PU}=$ Norfolk Ridge

$\mathrm{PZ}=$ Pandora Bank

$\mathrm{RN}=$ northem South Rennell Trough

$\mathrm{RU}=$ southeastern Woodlark Basin Rotation

$\mathrm{TE}=$ eastern Tasman Basin

$\mathrm{TM}=$ southern Dampier Ridge

$\mathrm{WA}=$ West Antarctica

WM $=$ New Guinea Trench line

$W N=$ northern Woodlark Basin

WR $=$ Woodlark Basin Rotation (western end)

$\mathrm{ZN}=$ northern Coral Sea Basin

$\mathrm{ZU}=$ New Guinea/Norfolk (PU) overthrusts 
changed and South Solomon (New Britain, San Cristobal, New Hebrides) subduction was initiated.

At $10 \mathrm{Ma}$, New Guinea (Wewak-Trobriand) subduction ended, South Solomon (New Britain, San Cristobal, New Hebrides) Arc volcanism began, and spreading was initiated in the North Fiji Basin. From $10 \mathrm{Ma}$ to the present, convergent motion occurred along the New Britain-San Cristobal-New Hebrides trenches and the Manus, Woodlark, North Fiji, and Lau-Havre basins dilated. Folding and obduction of the southern margin of the Ontong Java Plateau began about $5 \mathrm{Ma}$, concomitant with collision of the Woodlark Basin with the Solomon Island Arc. Collision and suturing of the New Britain forearc (a rifted fragment of the West Melanesian backarc) to the Papua New Guinea mainland (to form the northern New GuineaHuon Peninsula area) began at roughly $2 \mathrm{Ma}$.

As mentioned earlier, spreading in the North Fiji Basin was quite complicated. As basin dilation began at $10 \mathrm{Ma}$, half of the Fiji Platform (Viti Levu) was attached to the Vitiaz Arc on the Pacific Plate. From 10 to $7 \mathrm{Ma}$, the New Hebrides Arc moved to the southwest. Toward the end of this period ( $~ 8 \mathrm{Ma})$, Fiji also began to move with the rest of the New Hebrides Arc. Just before $7 \mathrm{Ma}$, the other half of the Fiji Platform (Vanua Levu) formed and clockwise rotation of the New Hebrides Arc was initiated as the Central North Fiji Basin (CNFB) triple junction developed. Once initiated, this rotation continued to the present. At roughly $6 \mathrm{Ma}$, Fiji was split from the New Hebrides Arc by the southern limb of the CNFB triple junction. From about 1.5 Ma until the present, a second spreading ridge (Viwa Rift) was active west of Fiji, with spreading there occurring contemporaneously with the southern limb of the CNFB triple junction located farther to the west. The ongoing basin dilation in the Manus and Lau basins also was initiated just before $5.5 \mathrm{Ma}$.

\section{CONCLUSION}

The reconstructions shown and discussed above, and those contained in the animated version on the CD ROM included in the pocket at the back of this volume, are intended to provide a simple graphic portrayal of some of the very complex plate motions that have occurred in the Southwest Pacific region during the past 100 m.y. These reconstructions should be useful aids to formulating ideas in disciplines where visualizing paleogeography is critical. Although they may need refinement as new information on the geology of the Southwest Pacific becomes available and new models of Pacific, I-A, and Antarctica plate motions are derived, we think that these reconstructions provide a realistic portrayal of the tectonic development of the Southwest Pacific.

\section{ACKNOWLEDGMENTS}

We thank the following persons: Fa Dwan, Lisa Gahagan, Joann Stock, and Paul Wessel for helpful technical support; Lillian $\mathrm{Ng}$ for essential technical assistance; Johanna Resig and Brian Taylor for useful comments; Keith Crook for a thorough review; and Diane Henderson and Brooks Bays for editorial and drafting assistance. Supplementary funding was provided by JOI/U.S. Science Support Program and the Geodynamics Research Institute, Texas A\&M University. This is University of Hawaii School of Ocean and Earth Science and Technology (SOEST) Contribution No. 2836.

\section{REFERENCES*}

Acton, G.D., and Gordon, R.G., 1990. Global plate motion circuits and motion between hotspots: a paleomagnetic test. Eos, 71:864.

\footnotetext{
* Abbreviations for names of organizations and publication titles in ODP reference lists follow the style given in Chemical Abstracts Service Source Index (published by American Chemical Society).
}

Cande, S.C., LaBrecque, J.L., Larson, R.L., Pitman, W.C., III, Golovchenko, X., and Haxby, W.F., 1989. Magnetic lineations of the world's oceans. $A A P G$, Map (scale 1:27,400,000).

Cande, S.C., Raymond, C.A., Haxby, W.F., Ryan, W.B.F., Tebbens, S., O'Hara, S., Mueller, D., O'Brien, B., and Wilkinson, M., 1992. Preliminary results of a hydrosweep swath bathymetry, magnetics and gravity survey of a Pacific-Antarctic Ridge FZ. Part I: Plate kinematics. Eos, 73:295-296.

Clague, D.A., and Dalrymple, G.B., 1989. Tectonics, geochronology, and origin of the Hawaiian-Emperor volcanic chain. In Winterer, E.L., Hussong, D.M., and Decker, R.W. (Eds.), The Eastern Pacific Ocean and Hawaii. Geol. Soc. Am., Geol. of North America Ser., N:188-217.

Dalziel, I.W.D., 1992. Antarctica, a tale of two supercontinents? Annu. Rev. Earth Planet. Sci., 20:501-526.

Duncan, R.A., 1981. Hotspots in the Southern Oceans-an absolute frame of reference for motion of the Gondwana continents. In Solomon, S.C., Van der Voo, R., and Chinnery, M.A. (Eds.), Quantitative Methods of Assessing Plate Motions. Tectonophysics, 74:29-42.

, 1991. Age distribution of volcanism along aseismic ridges in the eastern Indian Ocean. In Weissel, J., Peirce, J., Taylor, E., Alt, J., et al., Proc. ODP, Sci. Results, 121: College Station, TX (Ocean Drilling Program), 507-518.

Duncan, R.A., and Clague, D.A., 1985. Pacific plate motions recorded by linear volcanic chains. In Nairn, A.E.M., Stehli, F.G., and Uyeda, S. (Eds.), The Ocean Basins and Margins (Vol. 7A): The Pacific Ocean: New York (Plenum), 89-121.

Duncan, R.A., and McDougall, I., 1989. Plate tectonic setting. In Johnson, R.W. (Ed.), Intraplate Volcanism in Eastern Australia and New Zealand: Cambridge (Cambridge Univ. Press), 13-18.

Duncan, R.A., and Richards, M.A., 1991. Hotspots, mantle plumes, flood basalts, and true polar wander. Rev. Geophys., 29:31-50.

Engebretson, D.C., Cox, A., and Gordon, R.G., 1985. Relative Motions Between Oceanic and Continental Plates in the Pacific Basin. Spec. Pap., Geol. Soc. Am., 206.

Epp, D., 1978. Age and tectonic relationships among volcanic chains on the Pacific plate [Ph.D. dissert.]. Univ, of Hawaii, Honolulu.

Fleitout, L., and Moriceau, C., 1992. Short-wavelength geoid, bathymetry and the convective pattern beneath the Pacific Ocean. Geophys. J. Int., 110:6-28.

Harland, W.B., Armstrong, R.L., Cox, A.V., Craig, L.E., Smith, A.G., and Smith, D.G., 1990. A Geologic Time Scale 1989: Cambridge (Cambridge Univ. Press).

Hegarty, K.A., and Weissel, J.K., 1988. Complexities in the developments of the Caroline Plate region, western Equatorial Pacific. In Nairn, A.E.M., Stehli, F.G., and Uyeda, S. (Eds.), The Pacific Ocean: New York (Plenum), 277-301.

Hegarty, K.A., Weissel, J.K., and Hayes, D.E., 1983. Convergence at the Caroline-Pacific plate boundary: collision and subduction. In Hayes, D.E. (Ed.), The Tectonic and Geologic Evolution of Southeast Asian Seas and Islands (Vol. 2). Am. Geophys. Union, Geophys. Monogr., 27:326-348.

Jarvis, P.A., 1991. Tectonic deformation in the North Fiji Basin [Ph.D. dissert.]. Univ. of Hawaii, Honolulu.

Joshima, M., Okuda, Y., Murakami, F., Kishimoto, K., and Honza, E., 1987. Age of the Solomon Sea Basin from magnetic lineations. Geo-Mar. Lett., 6:229-234.

Jurdy, D.M., and Stefanick, M., 1991. Are plumes fixed? Or do they go with the flow? Eos, 72:445.

Kroenke, L.W., 1984. Cenozoic tectonic development of the Southwest Pacific. Tech. Bull.-U.N. Econ. Soc. Comm. Asia Pac., Comm. Co-ord. Jt. Prospect Miner. Resour. South Pac. Offshore Areas, 6.

Kroenke, L.W., and Eade, J.V., 1982. Three Kings Ridge: a west-facing arc. Geo-Mar. Lett., 2:5-10.

Kroenke, L.W., Smith, R., and Nemoto, K., in press. Morphology and structure of the seafloor in the northern part of the North Fiji Basin. In Kroenke, L.W., and Eade, J.V. (Eds.), Basin Formation, Ridge Crest Processes, and Metallogenesis in the North Fiji Basin. Circum-Pac. Counc. Energy Mineral Resour., Earth Sci. Ser.

Lapouille, A., 1982. Etude des bassins marginaux fossiles de Sud-Ouest Pacifique; Bassin Nord-d'Entrecasteaux, bassin Nord-Loyaute, bassin Sud-Fidjien, Contribution a l'etude geodynamique du Sud-Ouest Pacifique. Trav. Doc. ORSTOM, 147:409-438.

Larue, B.M., Daniel, J., Jouannic, C., and Recy, J., 1977. The South Rennell Trough: evidence for a fossil spreading zone. Int. Symp. on Geodynamics in South-west Pacific Noumea (New Caledonia). Paris (Editions Technip), 51-61. 
Lonsdale, P., 1988. Geography and history of the Louisville hotspot chain in the Southwest Pacific. J. Geophys. Res., 93:3078-3104.

Maillet, P., Monzier, M., Selo, M., and Storzer, D., 1982. La zone d'Entrecasteaux (Sud-Ouest Pacifique): nouvelle approche pétrologique et géochronologique. In Equipe de Géologie-Géophysique du Centre ORSTOM de Nouméa. Contribution a l'étude Géodynamique du Sud-Ouest Pacifique. Trav. Doc. ORSTOM, 147:441-458.

Malahoff, A., Feden, R.H., and Fleming, H.F., 1982. Magnetic anomalies and tectonic fabric of marginal basins north of New Zealand. J. Geophys. Res., 87:4109-4125.

Malahoff, A., Kroenke, L.W., Cherkis, N., and Brozena, J., in press. Magnetic and tectonic fabric of the North Fiji Basin and Lau Basins. In Kroenke, L.W., and Eade, J.V. (Eds.), Basin Formation, Ridge Crest Processes, and Metallogenesis in the North Fiji Basin. Circum-Pac. Counc. Energy Miner. Resour. Earth Sci. Ser.

Mayes, C.L., Lawver, L.A., and Sandwell, D.T., 1990. Tectonic history and new isochron chart of the South Pacific. J. Geophys. Res., 95:8543-8567.

Morgan, W.J., 1977. Computer programs for making maps and moving continents. Tech. Rep., Dep. Geol. Geophys. Sci., Princeton Univ.

1981. Hotspot tracks and the opening of the Atlantic and Indian Oceans. In Emiliani, C. (Ed.), The Sea (Vol. 7): The Oceanic Lithosphere: New York (Wiley), 443-487.

1983. Hotspot tracks and the early rifting of the Atlantic. Tectonophysics, 94:123-139.

Musgrave, R.J., 1989. A weighted least-squares fit of the Australian apparent polar wander path for the last $100 \mathrm{Myr}$. Geophys. J., 96:231-243.

Pringle, M.S., Jr., 1992. Geochronology and petrology of the Musicians Seamounts, and the search for hot spot volcanism in the Cretaceous Pacific [Ph.D. dissert.]. Univ. of Hawaii, Honolulu.
Royer, J.-Y., and Sandwell, D.T., 1989. Evolution of the eastern Indian Ocean since the Late Cretaceous: constraints from GEOSAT altimetry. J. Geophys. Res., 94:13755-13782.

Scotese, C.R., Gahagan, L.M., and Larson, R.L., 1988. Plate tectonic reconstructions of the Cretaceous and Cenozoic ocean basins. Tectonophysics, $155: 27-48$.

Shaw, R.D., 1979. On the evolution of the Tasman Sea and adjacent continental margins [Ph.D. dissert.]. Univ. of Sydney, Sydney.

Taylor, B., 1979. Bismarck Sea: evolution of a back-arc basin. Geology, 7:171-174.

, 1987. A geophysical survey of the Woodlark-Solomons region. In Taylor, B., and Exon, N.F. (Eds.), Marine Geology, Geophysics, and Geochemistry of the Woodlark Basin-Solomon Islands. Circum-Pac. Counc. Energy Mineral Resourc., 7:25-48.

Veevers, J.J., and Li, Z.X., 1991. Review of seafloor spreading around Australia. II. Marine magnetic anomaly modelling. Am. J. Earth Sci., 38:391-408.

Walcott, R.I., 1987. Geodetic strain and the deformational history of the North Island of New Zealand during the late Cainozoic. Philos. Trans. R. Soc. London, 321:163-181.

Weissel, J.K., and Anderson, R.N., 1978. Is there a Caroline Plate? Earth Planet. Sci. Lett., 41:143-148.

Weissel, J.K., and Hayes, D.E., 1977. Evolution of the Tasman Sea reappraised. Earth Planet. Sci. Lett., 36:77-84.

Yan, C.-Y., 1988. Indo-Australia plate motion determined from Australia and Tasman Sea hotspot trails [M.S. thesis]. Univ. of Hawaii, Honolulu.

Date of initial receipt: 14 September 1992

Date of acceptance: 22 October 1992

Ms 130B-055 

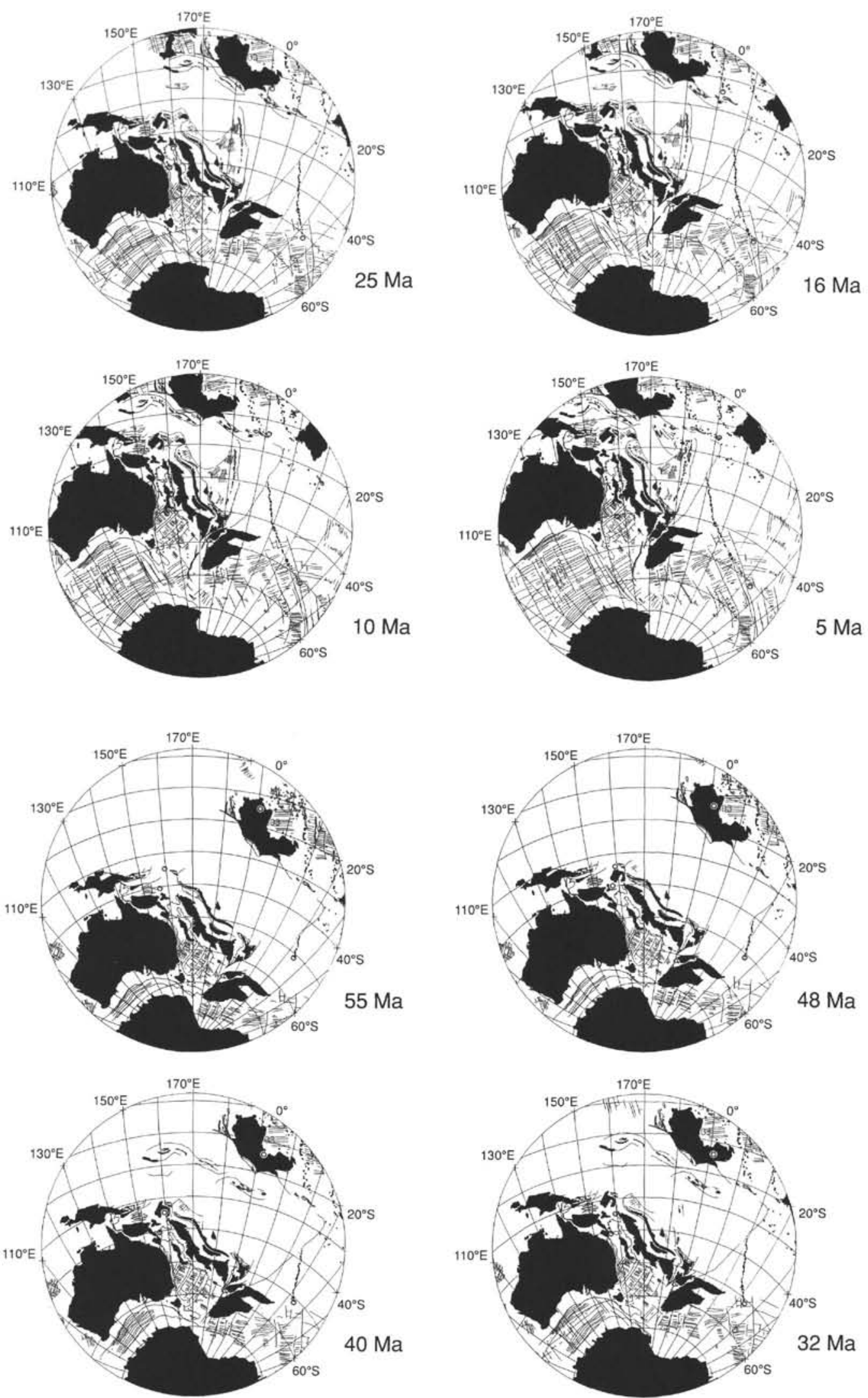

Figure 4. Plate reconstructions at $100,85,74,65,55$, and $48 \mathrm{Ma}$ (note the formation of the Louisiade Plateau over the Lord Howe hotspot), at $40 \mathrm{Ma}$ (note the alignment of the Vitiaz Arc, on strike with the rest of the North Solomon Arc, and the location of 'Eua, poised off the eastern end of New Caledonia), at $32 \mathrm{Ma}$ (note the position of the newly formed Three Kings Arc north of the New Zealand North Island, the location of 'Eua farther to the north in the South Fiji Basin, and the alignment of the Vitiaz Arc with the North Solomon Arc), and at 25, 16, 10, and $5 \mathrm{Ma}$. 
PLATE TECTONIC RECONSTRUCTION OF SW PACIFIC
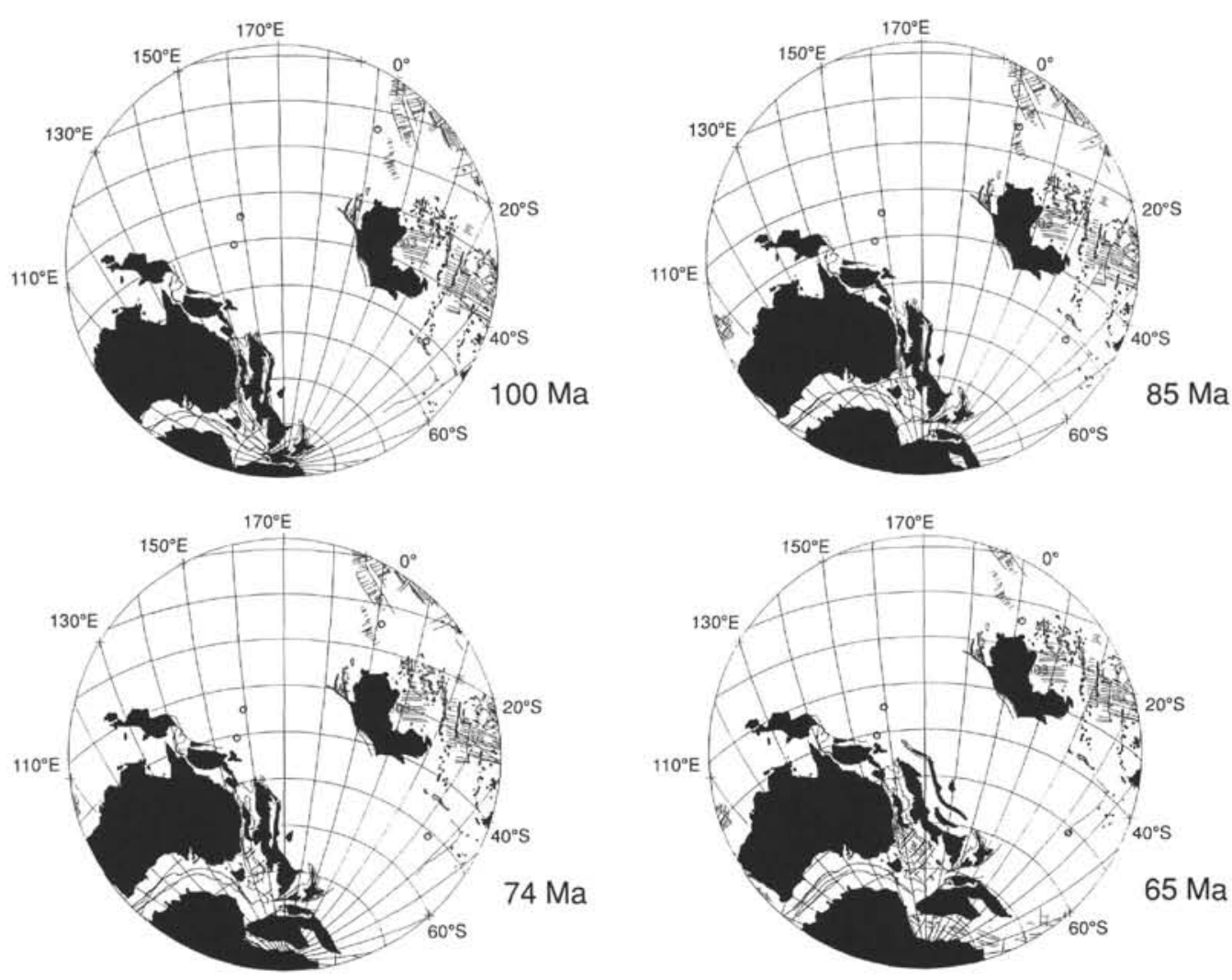

Figure 4 (continued).

709 